\title{
ANÁLISE DA MOBILIDADE COTIDIANA EM FLORIANÓPOLIS
}

\author{
ANALYSIS OF THE DAILY MOBILITY IN FLORIANÓPOLIS
}

\section{RESUMO}

O conceito de mobilidade é polissêmico e pode ser adjetivado para dar providência a diferentes explicações, dentre as quais destaca-se a mobilidade cotidiana, compreendida como aquela do trajeto de casa ao trabalho e vice-versa, cujas implicações forjam hábitos e práticas espaciais. Partindo desta acepção e com base na formação sócio-espacial, este artigo analisa como os Planos Diretores de Florianópolis constituíram a mobilidade cotidiana da cidade sob um paradigma desenvolvimentista e modernista que privilegia o automóvel individual. Por fim, verifica-se como a política de mobilidade atual de Florianópolis ainda obedece a esse paradigma, em que pese nacionalmente o estado da arte da literatura e das políticas públicas estar mais próximo dos conceitos de sustentabilidade e do direito à cidade.

Palavras-chave: Mobilidade Urbana; Florianópolis; Plano Diretor; Metropolização.

\section{ABSTRACT}

The concept of mobility is polysemous and can be used to provide different explanations, among which the daily mobility, understood as the one that best describes the journey from home to work and from work to home, whose implications forge habits and spatial practices. Starting from approach and based on the socio-spatial formation theory, the currently work aims to analyse how the Master Plans of Florianópolis constituted the daily mobility of the city under a developmental and modernist paradigm that privileges the individual automobile. It also verifies how the present mobility policy of Florianópolis still obeys this paradigm, although recent literature and public policies on this matter suggests concepts such as sustainability and the right to the city.

Keywords: Urban Mobility; Florianópolis; Master plan; Metropolization.

\author{
Emannuel dos Santos Costa ${ }^{a}$ \\ Elizângela Ribeiro Bosco ${ }^{a}$ \\ Zelindro Ismael Farias ${ }^{a}$ \\ D Erick de Santana Mello ${ }^{a}$ \\ Dauro de Bonis Almeida Simões ${ }^{\text {a }}$ \\ D) Jorge Rebollo-Squera ${ }^{a}$ \\ D Isa de Oliveira Rocha ${ }^{\text {a }}$ \\ a Universidade do Estado de Santa Catarina \\ (UDESC), Florianópolis, SC, Brasil
}

DOI: $10.12957 /$ geouerj.2020.39525

Correpondência: emannuel.costa@gmail.com

Recebido em: 20 fev. 2019

Revisado em: 19 ago. 2019

Aceito em: 22 ago.2019 


\title{
INTRODUÇÃO
}

Os assentamentos humanos sempre desafiaram a humanidade. Ao longo da história, eles figuram com funções distintas, remontando casos exitosos e outros tantos de insucesso. Para o ser humano paleolítico, por exemplo, os cemitérios e templos eram a função principal da modelagem de suas habitações. Mais adiante, a domesticação de animais e outras formas de vida dedicadas ao aprovisionamento de alimentos resultaram em aldeamentos (MUNFORD, 1982).

Esse período foi compreendido como a primeira grande "Revolução Tecnológica Agrícola". Os efeitos da mesma transformaram a condição humana de então, incrementando a demografia - comparável apenas com a da Revolução Industrial inglesa, na qual passou-se de vinte para seiscentos e cinquenta mil habitantes. Embora todas as revoluções precedentes tenham causado profundos efeitos sobre os assentamentos humanos, a partir das mais recentes se verificou a transformação efetiva da natureza em formas urbanas em praticamente todo o planeta. Nas revoluções industriais descobriu-se a energia inanimada para mover dispositivos mecânicos, tais como máquinas a vapor, motores elétricos e motores a explosão. Com isso, empreendeu-se uma poderosa tecnologia fabril e agrícola com grande incremento demográfico e a transformação da força de trabalho em mão-de-obra assalariada. Tais revoluções circunscreveram um processo civilizatório longo, por vezes lento, mas sempre permeado de conflitos políticos e sociais decorrentes dos avanços técnicos, da acumulação de capital ou dos recessos econômicos e dos muitos percalços para um número elevadíssimo de indivíduos e sociedades (MUMFORD, 1982; RIBEIRO, 2000).

Contudo, foi desse processo que as cidades se cristalizaram e se complexificaram, compondo um mosaico de tipologias urbanas, de localidades e regionalidades onde cada uma dessas ocorrências alterou a natureza ao produzir espaço acomodando interesses políticos e econômicos. Por conta disso, Milton Santos entende que "as formas espaciais seriam uma linguagem dos modos de produção (...), reforçando dessa maneira a especificidade de cada lugar" (SANTOS, 1977, p. 87). Ou seja:

\begin{abstract}
O espaço é a matéria trabalhada por excelência. Nenhum dos objetos sociais tem uma tamanha imposição sobre os homens, nenhum está tão presente no cotidiano dos indivíduos. A casa, o lugar de trabalho, os pontos de encontro, os caminhos que unem esses pontos, são igualmente elementos que condicionam a atividade dos homens e comandam a prática social. A práxis, ingrediente fundamental da transformação da natureza humana, é um dado socioeconômico, mas é também tributária dos imperativos espaciais (SANTOS, 1977, p. 92).
\end{abstract}

Logicamente, seria inviável uma tentativa de sintetizar todo o avanço da história urbana em poucos parágrafos, em que pese a noção de totalidade, tão central a teoria da formação sócio-espacial em Milton Santos (1977), se apresente como nosso leitmotiv. Contudo, o objeto de interesse deste trabalho ${ }^{1}$ reside

\footnotetext{
1 Este artigo é resultado de uma série de atividades, palestras e debates com especialistas realizados na disciplina de Estudos Avançados em Planejamento Territorial do curso de Doutorado em Planejamento Territorial e Desenvolvimento Socioambiental da Universidade do Estado de Santa Catarina - UDESC, no primeiro semestre de 2018.
} 
exatamente em compreender os caminhos que unem esses pontos de encontro e ligam a casa ao lugar de trabalho. Isto é: a maneira pela qual os deslocamentos dos indivíduos pelo espaço e no tempo condicionou e foi condicionada pelo desenvolvimento urbano.

Figura 1. Mapa de localização do município de Florianópolis. Fonte: elaboração dos autores.

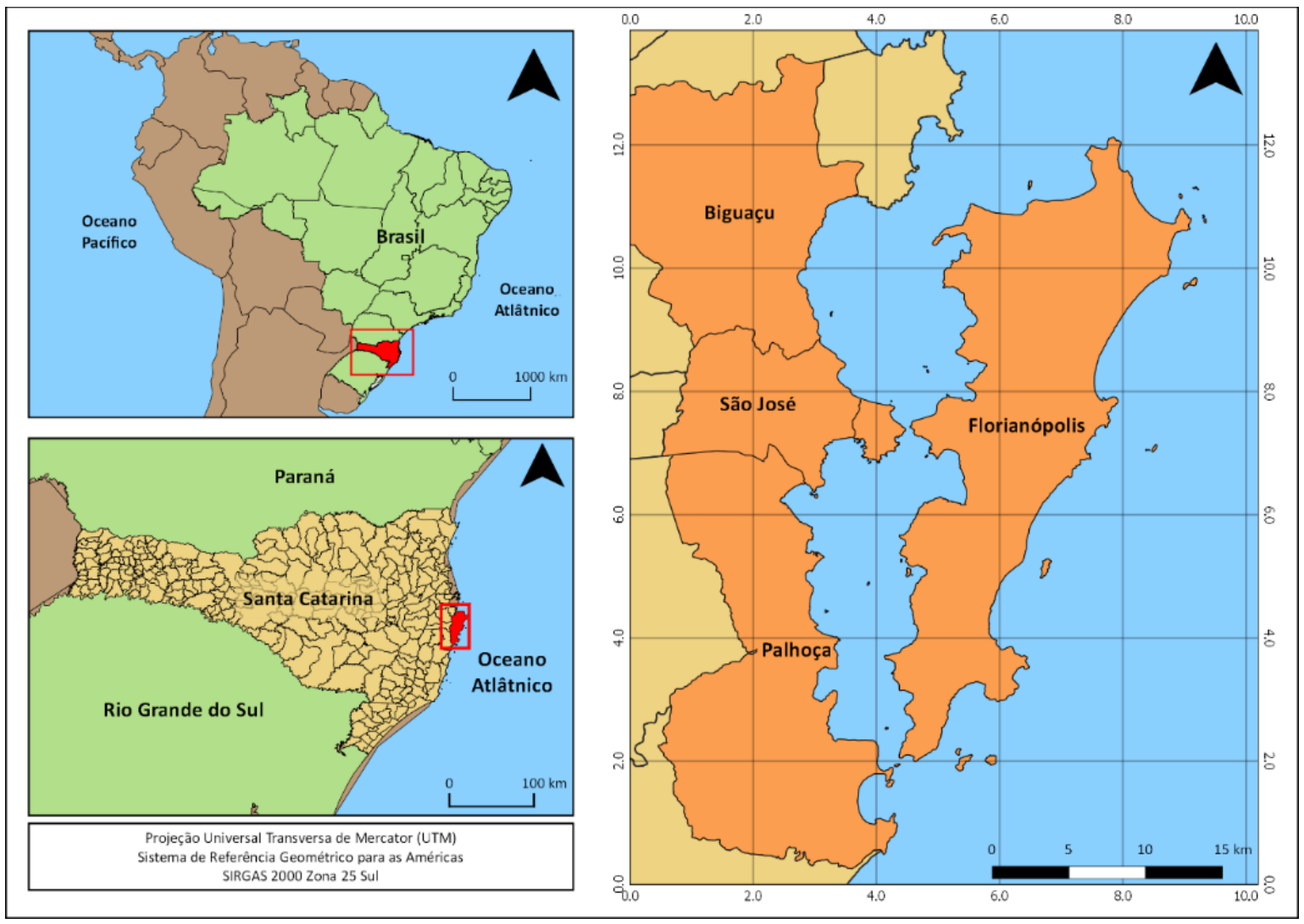

Tal empreendimento foi realizado tendo como recorte espacial o município de Florianópolis (figura 1), capital do estado de Santa Catarina, localizado na região Sul do Brasil e, como recorte temporal, o período compreendido desde a formulação do primeiro plano diretor da cidade, em 1955, até o atual, em vigência desde 2014.

\section{Tecendo conceitos sobre a mobilidade}

Umas das questões fundamentais para o entendimento do que vem a ser mobilidade reside no conjunto de seus significados, os quais vão muito além do ato simples de se deslocar. De acordo com Balbim (2016), a mobilidade é um termo polissêmico, muito confundido com outros conceitos e ideias, como as de circulação, acessibilidade, trânsito ou transporte. Para o autor, o conceito de mobilidade adquire acepções e presta-se a usos e explicações diversas. Da mobilidade cotidiana passou-se às mobilidades social, residencial e do trabalho - ou mobilidade simbólica, tal como vem sendo tratada mais recentemente. As migrações também são formas 
de mobilidade, bem como a mobilidade pendular, do turismo e do lazer, chegando até o nomadismo e ao imobilismo (BALBIM, 2016). Nesse sentido, Baldraia (2017) complementa afirmando que "a noção de mobilidade supera a ideia de deslocamento, pois traz para a análise suas causas e consequências, ou seja, a mobilidade não se resume a ação" (BALDRAIA, 2017, p. 32).

Esmiuçar a acepção de uma mobilidade para além do lato sensu, portanto, se faz necessário na medida em que a existência de diferentes sentidos para a empregabilidade deste termo requererão distintas estratégias teórico-conceituais para suas respectivas superações. Mais especificamente, em relação ao objeto deste artigo, o que se apresenta é um enquadramento conceitual em direção ao entendimento da mobilidade cotidiana, compreendida como aquela do trajeto de casa ao trabalho e vice-versa. Esta adjetivação corresponde, também, a temporalidades curtas e ritmos sociais da vida cotidiana, cujas implicações forjam hábitos e práticas espaciais (BALDRAIA, 2017). Assim, a mobilidade cotidiana se afirma enquanto proposição conceitual apropriada para trazer à luz tanto uma análise crítica a respeito da evolução das estratégias de deslocamento, modos de transportes e condições de acessibilidade pelo espaço no tempo projetadas nos planos diretores de Florianópolis, como também indicar caminhos para superação dos desafios sócio-espaciais colocados a este tipo de mobilidade pelo modelo de planejamento ainda vigente no Brasil.

A ausência de um planejamento urbano efetivo, no caso de cidades latino-americanas, impacta a mobilidade cotidiana e constitui-se em um dos principais entraves ao desenvolvimento urbano e qualidade de vida, em virtude da sucessão de planos de ordenamento responsáveis por distribuir sócio-espacialmente as aglomerações de forma dispersa e segregada. Segundo Abramo (2007), isto decorre de uma padronização de cidade, considerada pelo autor "COM-FUSA", ou seja, contraditória e difusa territorialmente. Esse ordenamento territorial urbano possui "forte ligação com o desempenho do sistema de mobilidade e as condições de deslocamentos da população" (CARVALHO, 2016, p. 346), ou seja, em cidades onde as atividades econômicas são pouco dispersas pelo território, observa-se uma tendência de massificação do automóvel individual em detrimento dos outros modais de deslocamento (motorizados ou não) gerando, portanto, um sistema de transporte voltado mais a interesses mercadológicos com externalidades negativas à sociedade (CARVALHO, 2016). Sobre isso, Gorz (2017) destaca que os automóveis passaram de essencial à circulação de pessoas a objeto de consumo e desejo, materializando o triunfo da ideologia burguesa no nível da prática cotidiana. Diferente de outros objetos de luxo, o automóvel individual oferece um exemplo contraditório, sendo desvalorizado pela sua própria difusão; porém, essa desvalorização prática ainda não causou a sua desvalorização ideológica, persistindo como o mito da aprovação e vantagem do automóvel individual (GORZ, 2017).

Conforme será demonstrado adiante, em Florianópolis esses elementos reforçam a problemática da mobilidade urbana - entendida a partir desse ponto como a mobilidade cotidiana per se - cujo agravamento 
coincide, inequivocamente, com o aumento contínuo da frota de veículos motorizados (ver figura 5) em descompasso com suas respectivas infraestruturas urbano-viárias, cuja reprodução é insuficiente e inelástica. Em contrapartida, alternativas de mobilidade como, por exemplo, investimentos em transportes coletivos ou em modos não motorizados de deslocamento, são deixadas de lado, levando ao colapso da mobilidade cotidiana em face de uma demanda maior do que a oferta - característica típica de cidades onde prevalece o capitalismo periférico, tal qual são as brasileiras.

Compreender a realidade da mobilidade urbana cotidiana das cidades brasileiras é, portanto, tarefa complexa. Para tanto, é necessário revisar não apenas de qual maneira foram estabelecidas as diretrizes dos planos de desenvolvimento urbano, como também apreender o contexto sobre o qual as propostas adotadas resultaram na estruturação de um modelo hegemônico, centrado no transporte rodoviário - carro, ônibus, caminhão, motocicleta etc. Uma reflexão possível pode ser realizada a partir de duas frentes: a imposição desenvolvimentista-rodoviarista para o Brasil e a influência urbanística modernista, cuja interação mútua resulta no que denominamos de binômio rodoviarista-modernista, a saber:

Imposição Desenvolvimentista-rodoviarista: o Século XX foi definitivo para o Brasil consolidar a sua matriz de desenvolvimento econômico através da industrialização, trazendo consigo a consequente mudança no padrão de investimentos no setor de transportes à medida em que este "tem importância fundamental na operação do sistema econômico, pois os serviços que produz serão, praticamente, absorvidos por todas as unidades produtivas" (BARAT, 1978, p. 4). Na fase anterior à industrialização o sistema de transportes brasileiro se desenvolveu de maneira isolada "segundo sistemas regionais que ligavam os importantes centros de produção e comercialização agrícola aos portos regionais" (BARAT, 1978, p. 113) favorecendo, portanto, uma complementariedade do sistema ferroviário e da navegação de cabotagem. Contudo, face à acelerada industrialização, o "transporte rodoviário desempenhou papel fundamental nesse estágio do desenvolvimento econômico" (BARAT, 1978, p. 114).

Claramente, não se pretende esgotar o debate sobre as escolhas da matriz de transportes no Brasil, entretanto ressalta-se a força do paradigma rodoviarista surgido durante o governo Vargas na década de 1940 (Plano Rodoviário Nacional) $)^{2}$ e levado adiante por diferentes governos, constituindo-se em modelo suprapartidário e supra-ideológico.

Influência urbanística modernista: paralelamente à consolidação da matriz rodoviarista de desenvolvimento, de maneira geral os planos urbanos das cidades brasileiras foram influenciados pelas ideias oriundas do urbanismo modernista, neste caso em Florianópolis, conforme será discutido adiante. Trata-se de

\footnotetext{
2 Lembra-se que embora privilegiando o rodoviarismo, no período Vargas igualmente ocorreu expressiva expansão da aviação e consolidação do sistema ferroviário no país (RANGEL, 2005).
} 
um paradigma emergido da revolução urbana europeia do Século XIX que acompanhou a revolução industrial, a partir da qual houve "pela primeira vez na história, um deslocamento do centro de produção da economia, que do âmbito rural/agrícola/feudal transferiu-se para a ambiência urbana” (SIMÕES JR., 2007, p. 2). Na prática, esse processo de transformação do espaço se deu em função da ascensão da burguesia como classe social, que ocupando-se das funções administrativas municipais, corroborou no processo de modernização urbana, produzindo "uma cidade de características burguesas, marcadas por intervenções de caráter embelezador, dominadas pela estética do ecletismo, e que consequentemente reforçavam a segregação sócio-espacial" (SIMÕES JR., 2007, p. 3).

No que tange aos deslocamentos, via de regra os projetos modernistas reproduziram um caráter burguês, ao mesmo tempo em que acompanharam tendências de industrialização verificadas, sobretudo, na ascensão do automóvel. Trata-se, em síntese, de um paradigma que desde sempre gerou campo fértil à construção do imaginário do carro como elemento estruturante da cidade funcionalista. Ou, nas palavras do arquiteto urbanista Le Corbusier, um dos maiores expoentes deste movimento:

\footnotetext{
As cidades farão parte do país; Eu viverei a 30 milhas do meu escritório em uma direção, sob um pinheiro, minha secretária viverá a 30 milhas de distância também, a partir de outra direção, sob outro pinheiro. Cada um terá o seu próprio carro. Vamos usar até pneus, desgastar estradas e engrenagens, consumir óleo e gasolina. Tudo o que exigir uma grande quantidade de trabalho... Suficiente para todos (LE CORBUSIER apud DUANE et. al, 2010, p. 3).
}

Isto posto, ao se encontrarem na pauta do ordenamento territorial, ambas as perspectivas - urbanística e desenvolvimentista-rodoviarista - formaram uma espécie de afinidade eletiva ${ }^{3}$ cujo resultado mantém-se pertinente até hoje: cidades concebidas - no imaginário, no desenho e na vontade política - simpaticamente aos transportes rodoviários. Ademais, presume-se também que a vida urbana brasileira se estruturou sobre este binômio, a partir do qual os deslocamentos de casa para o trabalho e vice-versa, feitos preferencialmente com o carro, foram reduzidos à própria ideia de mobilidade.

Para Gomide, “o rápido e intenso crescimento urbano que ocorreu no Brasil a partir da década de 1950 foi acompanhado de mudanças profundas no sistema de mobilidade das pessoas. Aumentaram os deslocamentos feitos com veículos motorizados, notadamente o de automóveis particulares e ônibus" (GOMIDE, 2016, p. 245). O autor ainda destaca que o estímulo ao uso de automóveis particulares e a oferta inadequada de transporte coletivo além de causarem prejuízos à parcela mais pobre da população e provocarem aumento dos níveis de poluição e de congestionamentos, drenam mais recursos para ampliação

\footnotetext{
${ }^{3}$ Numa acepção menos conectada à significação literalmente weberiana deste termo e mais próxima de uma tentativa alegórica de adjetivação. Isto é, concorda-se com Löwy (2014), para quem Weber não chega a definir exatamente o que vem a ser uma "afinidade eletiva", mas evidencia o funcionamento deste conceito como "processo pelo qual a) duas formas culturais/religiosas, intelectuais, políticas ou econômicas; ou b) uma forma cultural e o estilo de vida e/ou os interesses de um grupo social entram [...] numa relação de atração e influência recíprocas, de escolha ativa, de convergência e de reforço mútuo" (LÖWY, 2014, p. 71-72).
} 
e construção de novas vias (GOMIDE, 2016). Trata-se da própria insustentabilidade do paradigma em cosntante reprodução.

Os primeiros avanços significativos para superação deste paradigma são verificados, no âmbito das políticas públicas para a mobilidade urbana, apenas recentemente, em face à redemocratização brasileira. Mais especificamente, destaca-se a promulgação da Constituição Federal de 1988, que "abriu espaço para uma série de modificações na política urbana brasileira, tanto no campo do ordenamento territorial e do desenvolvimento urbano [...] quanto no campo da mobilidade urbana" (CARVALHO, 2016, p. 346), a partir da qual, posteriormente, se instituiu a Política Nacional de Mobilidade Urbana - PNMU (BRASIL, 2012).

Basicamente, a PNMU estabeleceu os preceitos constitucionais à luz da sustentabilidade. Apesar do Estatuto da Cidade - de 2001 - ter contemplado diretrizes para a política urbana já uma década antes, foi somente após a promulgação da PNMU que se observou um direcionamento à mobilidade urbana sustentável no país com respaldo legal e político. Dentre os princípios mais importantes da PNMU, destacam-se: a acessibilidade universal; a equidade no uso do espaço público de circulação, vias e logradouros; a prioridade dos modos de transporte não motorizados e dos veículos motorizados coletivos sobre os motorizados individuais; e a redução da igualdade e promoção de inclusão social (BRASIL, 2012). O que se desenhou "como alternativa para o planejamento de cidades sustentáveis hoje é a introdução efetiva, no território, do conceito de mobilidade sustentável, que vai além do planejamento setorizado, seja ele dos usos do solo, da circulação ou dos transportes" (RODRIGUES DA SILVA et al., 2016, p. 82). Inferindo o potencial da nova política, Affonso (2016) observou apropriadamente a consolidação de um novo momento do pensamento sobre mobilidade urbana no Brasil, pautado na ascensão do direito à cidade como elemento estruturante da política urbana, no qual as ruas devem ser tomadas por "faixas exclusivas de ônibus e ciclovias, ciclo-faixas, praças e calcadas acessíveis iniciando pelas vagas para estacionamentos e leito carroçável ocupado irregularmente pelos carros" (AFFONSO, 2016, p. 87).

A ideia da mobilidade sustentável convalidada nas legislações atuais vai, portanto, ao encontro da mobilidade cotidiana desejável em Balbim (2016) e Baldraia (2017): uma formulação paradigmática voltada a ajustar diferentes necessidades de deslocamento das pessoas pelo espaço de maneira sustentável do ponto de vista ambiental e socioeconômico, invertendo a matriz hegemônica do automóvel individual e conferindo aos indivíduos o protagonismo da práxis sobre o espaço, tal como precedido por Milton Santos (1977). Dessarte, é vital compreender se, e em qual medida, a mobilidade cotidiana de Florianópolis ainda é produto do rodoviarismo-modernismo ou já corresponde ao referido estado da arte das políticas públicas para mobilidade urbana no Brasil. 
Guardadas as particularidades referentes à sua formação sócio-espacial, em Florianópolis verificou-se que os planos de desenvolvimento urbano implantados a partir da segunda metade do Século XX acompanharam o paradigma rodoviarista-modernista. Desse modo, é interessante recuperar a maneira pela qual a cidade se constituiu territorialmente até 1950, e principalmente após essa data, quando foram elaborados os planos urbanos de 1955 e posteriormente de 1976, 1984 e 1997. Desta tentativa de síntese infere-se a razão pela qual a mobilidade cotidiana em Florianópolis, historicamente, foi subordinada ao caráter funcionalista do planejamento, no qual o espaço urbano é paulatinamente adaptado à sorte dos meios de deslocamentos automotores, sobretudo o carro. A saber:

Notas sobre a formação sócio-espacial de Florianópolis: a conquista do território do estado de Santa Catarina por luso-brasileiros data do Século XVII, mais especificamente pela criação de núcleos visando à ocupação do litoral meridional do império português. Desta missão, resultaram as fundações das primeiras cidades catarinenses, em particular de Nossa Senhora do Desterro - atualmente Florianópolis - em 1673. Contudo, apenas por volta de 1750 foi realizado um processo colonizador de fato, com a chegada de casais oriundos do arquipélago de Açores (Portugal) que foram instalados em pequenas propriedades e conformaram freguesias espalhadas pela ilha de Santa Catarina e ao longo do litoral do estado. Economicamente, essas comunidades se desenvolveram com base em uma pequena produção mercantil pesqueira e agrícola até a primera metade do Século XX (SILVA, 1992; MAMIGONIAN, 1998; BASTOS, 2000), período no qual se verificou a decadência deste modelo. Isto ajuda a explicar porque o crescimento urbano de Florianópolis era considerado fraco, "[...] pois a cidade perde gradativamente sua importância no contexto regional e nacional, passando a exercer praticamente apenas sua função administrativa de capital do estado de Santa Catarina" (BASTOS, 2000, p. 132).

Plano Diretor de 1955: tal cenário de crise colocou Florianópolis sob disputa de poder entre os dois principais grupos oligárquicos da época, representados pelo "Partido Social Democrata (PSD), liderado pela família dos Ramos e a União Democrática Nacional (UDN), pelas famílias Konder-Bornhausen" (SOUZA, 2010, p. 52). No centro do debate reapareceu a ideia de mudar a capital para o interior do Estado, "levando-se em consideração a estagnação econômica que vivia Florianópolis nesse período e o fato da UDN manter seu domínio eleitoral em outra região de Santa Catarina" (SOUZA, 2010, p. 53). Diante da situação, surgiu por parte da elite local - majoritariamente do PSD - um discurso pró-modernização para a cidade. Nessa conjuntura, o planejamento urbano foi adotado como instrumento para alavancar o desenvolvimento, à despeito do que era observado em outras cidades brasileiras à epoca.

Devido a esse expediente, foi imposta uma concepção de malha viária, cuja sobreposição à organização do espaço vigente até então, baseada em estruturas de pequenas propriedades originárias da ocupação açoriana - caracterizadas por frentes estreitas e fundos compridos, tipo waldhunfendörf (MAMIGONIAN, 
1958) - gerou ruptura do modelo originário em detrimento do planejamento modernista. Tal quebra de escala incidiu diretamente nos desafios colocados à mobilidade urbana desde então, na medida em que forjou uma rugosidade (SANTOS, 1977) fundiária responsável por densificar a ocupação em razão da comercialização informal e desordenada de pequenos lotes integrantes das glebas, encravados e conectados por acessos estreitos e comuns (servidões), com entrada e saída para a mesma via principal (formato espinha de peixe).

Florianópolis cedeu à tendência do planejamento urbano modernista e ao contexto nacionaldesenvolvimentista, culminando na elaboração do primeiro Plano Diretor da cidade, assinado pelos arquitetos Edvaldo Pereira Paiva, Demétrio Ribeiro e Edgar Graeff. Inspirado na Carta de Atenas, no tocante ao que seria a mobilidade de hoje, o plano "previa um sistema rodoviário eficiente e que pudesse conectar toda a área urbana central, e também conectar a área urbana da ilha e a do continente" (SOUZA, 2010, p. 83) estabelecendo, portanto, prioridade para os veículos automotores. Foi empreendido um esforço no sentido de ampliar e modernizar as vias existentes (figura 2), juntamente à criação de outras, de maneira a estruturar grandes eixos viários e hierarquizar o sistema de circulação.

Figura 2. comparação do sistema viário existente com o proposto no Plano de 1955. Fonte: extraído de Souza (2010, p. 84).

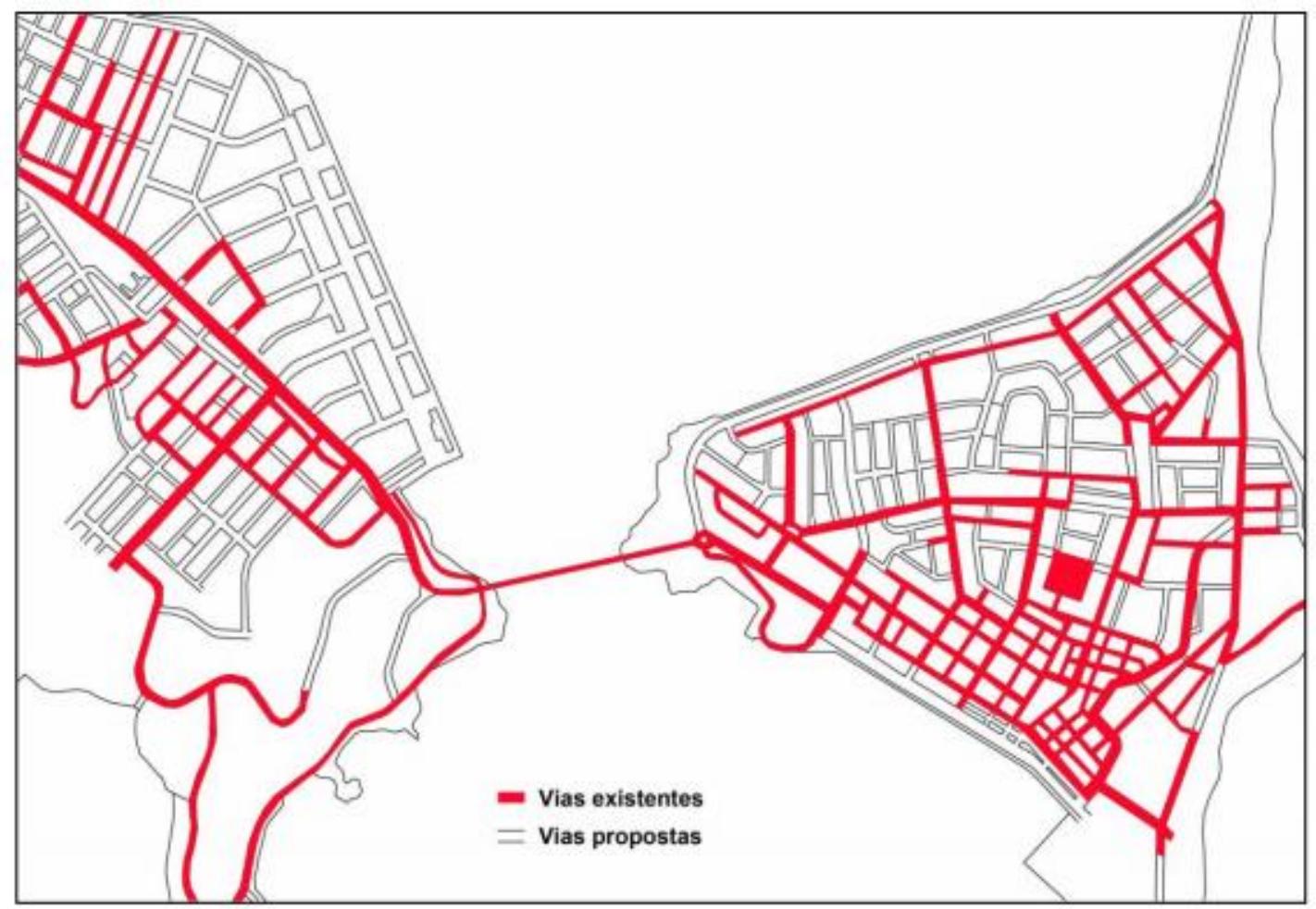

No entanto, durante seu período de vigência, o sistema viário proposto pouco evoluiu, basicamente porque abarcou apenas o perímetro urbano constituído à época, consequentemente não absorvendo as demandas surgidas a partir da continuidade da urbanização espontânea de Florianópolis e seu entorno. Assim, o plano entrou em obsolecência já na década seguinte. Contudo, destaca-se a construção da Avenida Beira- 
Mar Norte durante a década de 1960, pois a partir dela observou-se um movimento - ainda embrionário - do que veio a ser posteriormente a expansão imobiliária em direção ao norte da ilha, ocorrida em função do interesse de uma fração da burguesia local detentora de terras naquela região (SUGAl, 1994). Essa expansão foi essencial para o desenvolvimento urbano de Florianópolis.

Plano Diretor de 1976: O incipiente boom imobiliário das décadas de 1960 e 70 não impactou a "transformação da base econômica, a indústria do aglomerado urbano de Florianópolis não possuía expressão no contexto estadual, e, além disso, a zona rural mantia-se estagnada" (ROCHA, 2014, p. 9). Embora a orientação rodoviarista-modernista ainda fosse hegemônica, "começava-se a valorizar, também, que a gestão de uma cidade deveria levar em conta a sua área de influência, visto que as cidades vizinhas, dependentes de Florianópolis, estariam completamente condicionadas às modificações instituídas na capital" (CRAVO et. al, 2016, p. 7). Mais uma vez, as elites políticas uniram forças para construir uma segunda agenda de desenvolvimento, agora voltada a instituir uma região metropolitana, que resultou em uma proposição ainda mais dogmática do que a anterior - do ponto de vista rodoviarista-modernista - capitaneada pelo arquiteto Luiz Felipe Gama D'eça: o Plano de Desenvolvimento Integrado Metropolitano, em cuja proposta destacou-se o desenvolvimento voltado ao turismo e aos serviços na Ilha (SUGAI, 1994; PEREIRA, 2000).

Entendendo a necessidade de integrar o planejamento em sua escala regional, em 1971 foi criado o Plano de Desenvolvimento da Área Metropolitana de Florianópolis (PDAMF), o qual "serviu de base para uma proposta do governo de Santa Catarina que visava à transformação da capital do estado em um pólo regional de desenvolvimento" (CRAVO et. al, 2016,p. 8). Por outro lado, o projeto ratificou a força do modelo rodoviarista-modernista, consequentemente reforçando o imaginário do carro como elemento da práxis urbanística. Isto é observado ao comparar o desenho do centro metropolitano do PDAMF à construção Brasília e aos projetos de Le Corbusier, nos quais identifica-se semelhanças enre linhas funcionais, descontinuidade do espaço urbano e repetição de formas (PEREIRA, 2000).

Todavia, por conta da escassez de recursos a prefeitura de Florianópolis desenvolveu somente as propostas competentes para si (PEREIRA, 2000; SANTOS, 2015) e o recém-criado Instituto de Planejamento Urbano de Florianópolis - IPUF estruturou o Plano Diretor de 1976 a partir do PDAMF. Em suma, esse plano programou expansão urbana para os setores correspondentes hoje ao centro de Florianópolis, Universidade Federal de Santa Catarina - UFSC e para o chamado setor ocêanico de turismo, um "complexo habitacional ligado à recereação, ao lazer e à promoção de turismo, abrangendo a área de Rio Vermelho, Campeche, Lagoa e Ressacada"" (FLORIANÓPOLIS, 1976), conforme indicado na figura 3.

\footnotetext{
${ }^{4}$ A região da Ressacada não é um distrito oficial, mas compreende atualmente os bairros Carianos e Base Aérea. É também onde localiza-se o Aeroporto Internacional de Florianópolis.
} 
Figura 3. mapa de localização das áreas de expansão urbana programadas no Plano Diretor de 1976. Fonte: elaboração dos autores.

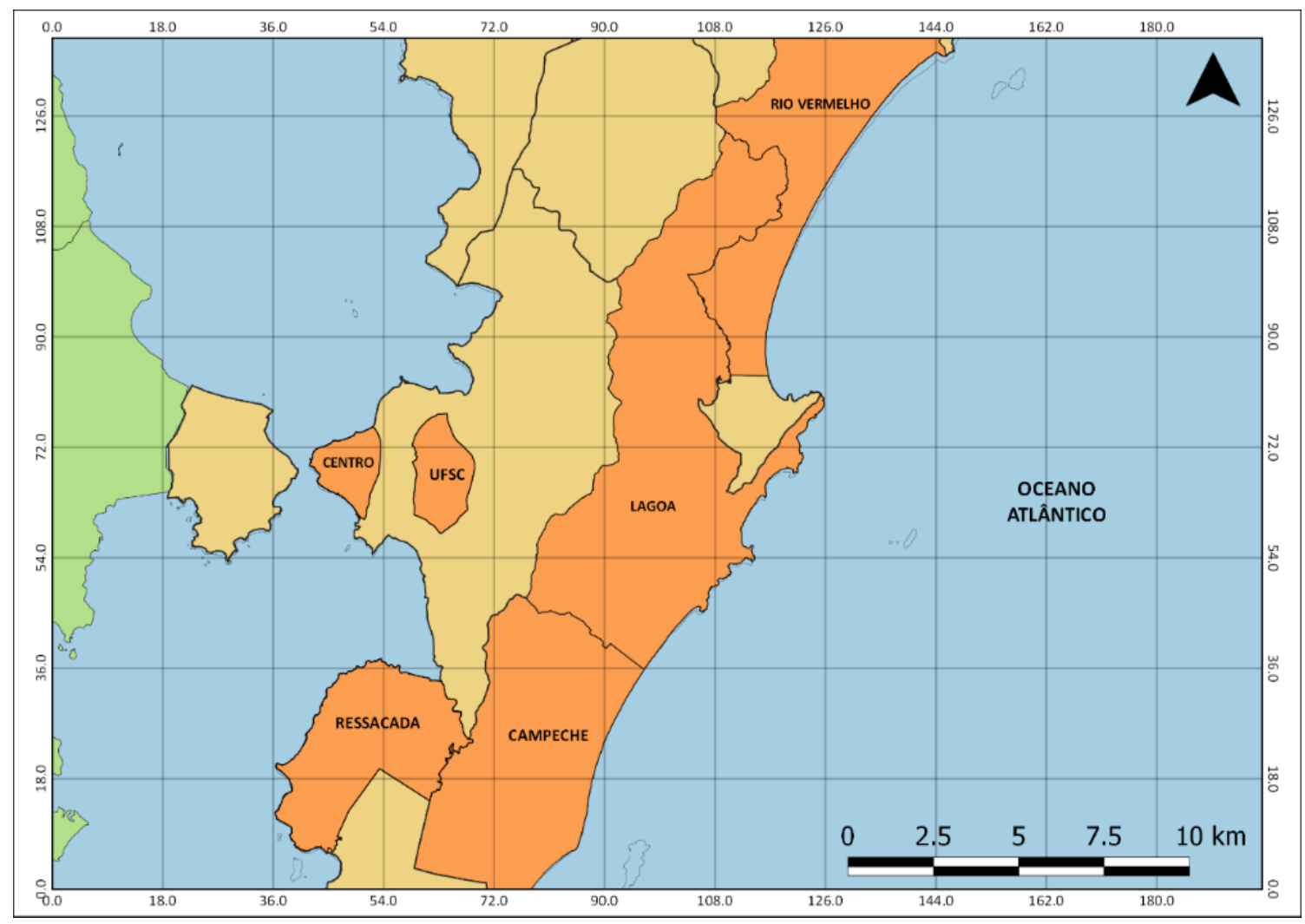

O plano entendia Florianópolis como "um único complexo urbano, compreendendo duas zonas distintas (nota: insular e continental) [...] mas unificadas em objetivos comuns de um processo de desenvolvimento integrado" (FLORIANÓPOLIS, 1976). Contudo, questiona-se esse princípio ao lembrar que Pereira (2000) flagrou as descontinuidades do espaço urbano descortinadas já no desenho modernista do PDAMF. Tal descontinuidade também é observada por Sposito (2011) que atribui esse processo ao próprio surgimento do automóvel, que colocou em xeque "a ideia de cidade como unidade, elemento que conforma, por sua vez, a ideia de rede urbana ou sistema urbano como conjunto de cidades em si" (SPOSITO, 2011, p. 133). Portanto, a incorporação da inspiração lecorbusiana de Gama D’eça neste plano sugere a consolidação da matriz automobilística como a própria matriz da mobilidade "que possuía o objetivo de realizar a integração viária da microrregião de Florianópolis" (COSTA, 2014, p. 57).

Em última análise, tratou-se inicialmente de uma proposta de escala regional cuja gênese, apropriadamente, visava solucionar o impasse da integração metropolitana. Contudo, em função de uma apropriação parcial e isolada por parte da prefeitura e do recém-criado IPUF, forjou-se um produto do planejamento funcionalista, que estabeleceu uma espécie de padrão linear de desenvolvimento urbano, à medida que o trajeto casa - trabalho - casa foi significado como bairro - centro - bairro. Esta opção pela unicentralidade vai ao encontro do assinalado por Corrêa, para quem "de fato, a Área Central constitui-se no 
foco principal não apenas da cidade mas também de sua hinterlândia. Nela concentram-se as principais atividades comerciais, de serviços da gestão pública e privada, e os terminais de transportes inter-regionais e intra-urbanos" (CORRÊA, 1989, p. 38). Logo, ao estabelecer este caráter unicentral dos fluxos, o Plano Diretor de 1976 condicionou a mobilidade da ilha, do continente e das cidades vizinhas ao próprio sistema rodoviarista baseado no automóvel.

Planos Diretores de 1985 e 1997: ao contrário dos antecessores, os planos diretores de Balneários (1985) e do Distrito Sede (1997) não empreenderam novas propostas de desenvolvimento urbano e/ou regional e concentraram-se, basicamente, em produzir os aprimoramentos necessários para controlar e instituir parâmetros mais refinados sobre os limites construtivos (figura 4). Em síntese, ambos os planos trataram de regulamentar "o uso e a ocupação do solo, especialmente quanto à localização, o acesso a implantação das edificações e aos outros limites do direito de construir" (FLORIANÓPOLIS, 1985; 1997). De modo geral, a mobilidade foi operada na mesma estrutura funcionalista e unicentral estabelecida pelo plano diretor de 1976.

Figura 4. mapa dos zoneamentos dos Planos Diretores de 1985 e 1997. Fonte: elaboração dos autores.

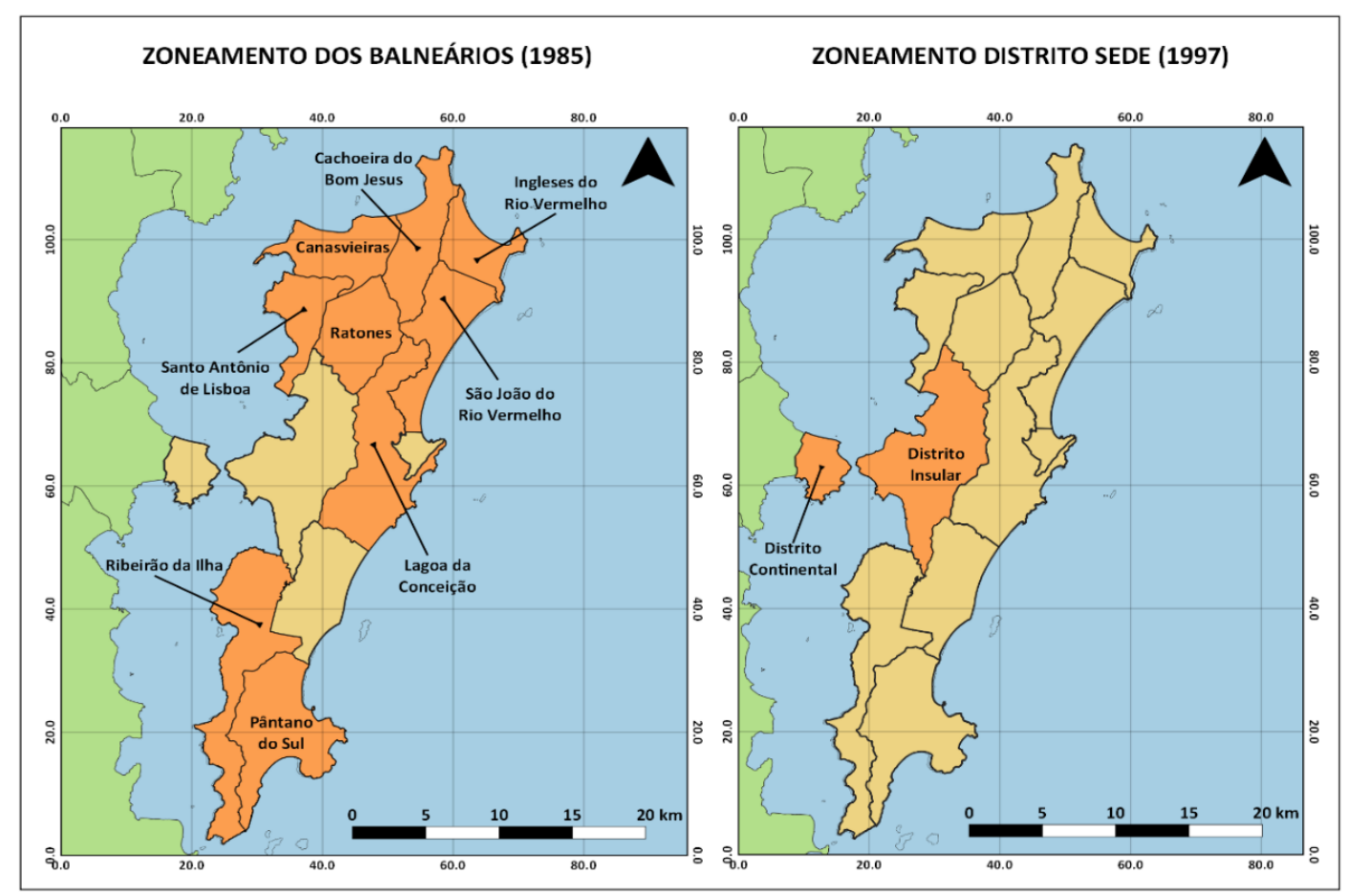

No primeiro, foi dada prioridade ao ordenamento dos balneários localizados na parte insular da cidade, compreendidos nos atuais distritos de Santo Antônio de Lisboa, Ratones, Canasvieiras, Cachoeira do Bom Jesus, Ingleses do Rio Vermelho, São João do Rio Vermelho, Lagoa da Conceição, Ribeirão da Ilha e Pântano do Sul. Já o segundo Plano, promulgado em 1997, institiuiu "o novo Plano Diretor de Uso e Ocupação do Solo no Distrito Sede do Município de Florianópolis" (FLORIANÓPOLIS, 1997). O Distrito Sede compreende o 
perímetro urbano continental competente ao munícipio - sendo este o distrito continental - e um perímetro insular compreendendo a área central acrescida de alguns bairros adjacentes, tendo como limite norte o bairro de Cacupé e limite sul o bairro do Rio Tavares - compondo o distrito insular.

\section{O estado da arte da mobilidade cotidiana em Florianópolis: estudos balizadores do Plano Diretor} Participativo de 2014

Os planos de desenvolvimento urbano elaborados para Florianópolis no século passado legaram dois elementos imprescindíveis a qualquer análise sobre sua mobilidade cotidiana atualmente: i) estruturaram toda malha urbana sob a égide do binômio rodoviarista-modernista e ii) conferiram característica de centralidade da área central do município em relação à sua hinterlândia. Em decorrência, o contexto com o qual a cidade se deparou a partir do ano 2000 não poderia ser outro senão o de preocupação com sua mobilidade urbana: se havia, nesta época, um clima generalizado de otimismo, ecoado no reconhecimento nacional e internacional da capital com melhor qualidade de vida ${ }^{5}$ ou vocação para o turismo de verão ${ }^{6}$ e de negócios ${ }^{7}$, igualmente a população se acostumou, não muito mais tarde, a lidar com manchetes como "pior mobilidade urbana do Brasil" 8 "pior cidade do país para dirigir".

Acrescente-se ainda a esses eventos que Florianópolis também refletiu os efeitos provocados pelas políticas federais de redução da carga tributária na indústria automobilística (SENHORAS, 2012), somadas à difusão do acesso ao carro em função do aumento de poder aquisitivo da população e da facilidade de obtenção de crédito verificadas especialmente entre 2003 e 2010 (período do governo Lula), numa interação que conferiu ao automóvel um papel fundamental na regulação da economia brasileira - embora indo de encontro aos avanços das políticas públicas para a mobilidade urbana promovidas no mesmo governo. Nesse sentido, observa-se no figura 5 que o índice de veículos automotores por habitante em Florianópolis frequentemente cresce o dobro em relação ao índice nacional (2002-2017).

Diante desse panorama e com o Estatuto da Cidade em 2001 estabelecendo a obrigatoriedade de Planos Diretores serem participativos e abrangerem todo o território municipal, inaugurou-se uma nova etapa do desenvolvimento urbano de Florianópolis à medida que o plano em vigência, de 1997, não atendia a nenhuma das duas exigências. Dois estudos preliminares balizaram as diretrizes de mobilidade adotadas pelo novo Plano Diretor Participativo (PDP) de 2014: o Floripa 2030 e o Plano da Mobilidade Urbana Sustentável da Grande Florianópolis (PLAMUS).

\footnotetext{
5 De acordo com o IDHM 2010 (PNUD et. al, 2013)

${ }^{6}$ The New York Times, 08/01/2009

7 Newsweek, 07/02/06

8 Diário Catarinense, 26/05/09

${ }^{9}$ Diário Catarinense, 03/11/17
} 
Figura 5. índice de veículos motorizados por habitante entre 2002 e 2017. Fontes: IBGE ${ }^{10}$, Denatran e Detran-SC ${ }^{11}$.

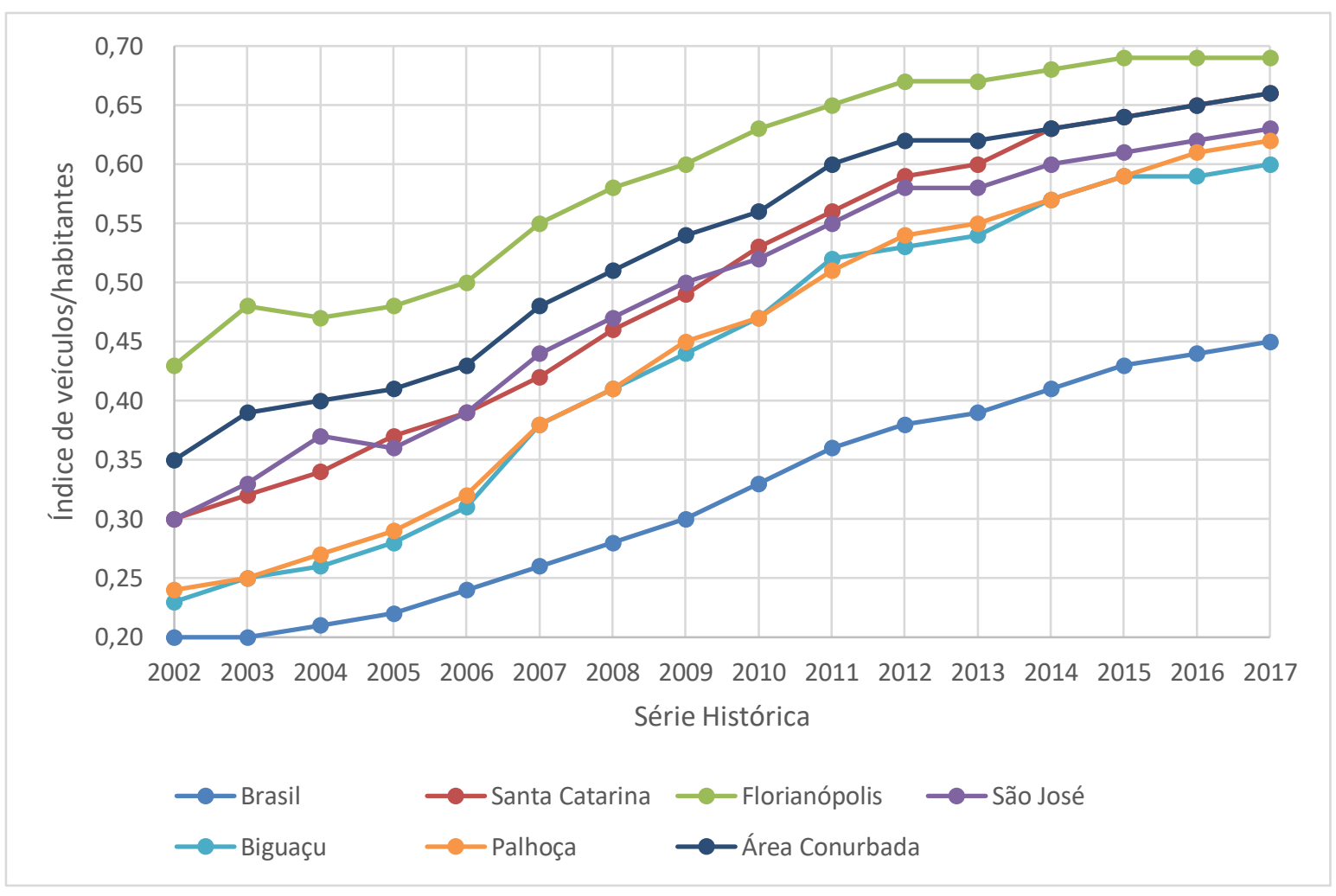

Floripa 2030: os primeiros estudos iniciaram em meados da década de 2000, mas foi a partir de 2006, com a entrada do arquiteto argentino Rubén Pesci ${ }^{12}$ e sua equipe no projeto, que uma nova proposta de desenvolvimento começou a ganhar forma. Sob sua coordenação metodológica, foi realizado um trabalho colaborativo com "148 pessoas, representando 84 entidades formado por representações das instituições da região e de segmentos sociais, especialmente convidadas para comporem a grande equipe de formulação das propostas" (FLORIPAMANHÃ, 2008, p. 3) denominado “Floripa 2030: agenda de desenvolvimento sustentável de Florianópolis" (FLORIPAMANHÃ, 2008) ${ }^{13}$. Dentre as cinco estratégias resultantes deste projeto, duas endereçaram diretamente o debate: “Estratégia 2 - cidade multicultural e polinuclearidade" e "Estratégia 4: demanda de maior mobilidade pública".

À estratégia 2, elaborou-se exatamente sobre a necessidade de romper com a concentração dos fluxos na área central através da criação de novas centralidades com vistas a reduzir a quantidade de deslocamentos.

\footnotetext{
${ }^{10}$ De acordo com as estimativas populacionais oficiais de cada ano, exceto para 2010 quando foi utilizado o Censo oficial do IBGE. 11 Foram considerados para esta análise os seguintes tipos de veículos motorizados: automóvel, ônibus, micro-ônibus, caminhões, caminhonetes, camionetas, utilitários, motocicletas e motonetas, licenciados oficialmente segundo dados do Departamento Nacional de Trânsito - DENATRAN e do Departamento Estadual de Trânsito de Santa Catarina - DETRAN/SC.

12 Conforme clipping da organização Floripamanhã: http://floripamanha.org/2006/08/participacao-estrangeira-no-plano-diretor/.

${ }^{13}$ Embora o Floripa 2030 não seja objeto de análise deste artigo, ressalta-se que o projeto aventa questionamentos, sobretudo quanto ao tipo de participação empreendida, de adesão privada: o processo foi conduzido somente com entidades e membros convidados pelos organizadores. Sobre isso, recomenda-se o trabalho de Aguiar (2015) que analisou o caráter hegemônico de concepção do projeto.
} 
Assim, há uma concordância com a análise realizada até aqui, quando o projeto defende que "a necessidade pela busca do centro da cidade [...] acaba por gerar deslocamentos pendulares entre o centro e os subúrbios, ou mesmo, entre o centro e os municípios vizinhos que não supram essas necessidades em si próprios (FLORIPAMANHÃ, 2008, p. 38).

Figura 6. proposta de novas centralidades e o eixo duplo H do projeto Floripa 2030. Fonte: extraído de FLORIPAMANHÃ (2008, p. 53).

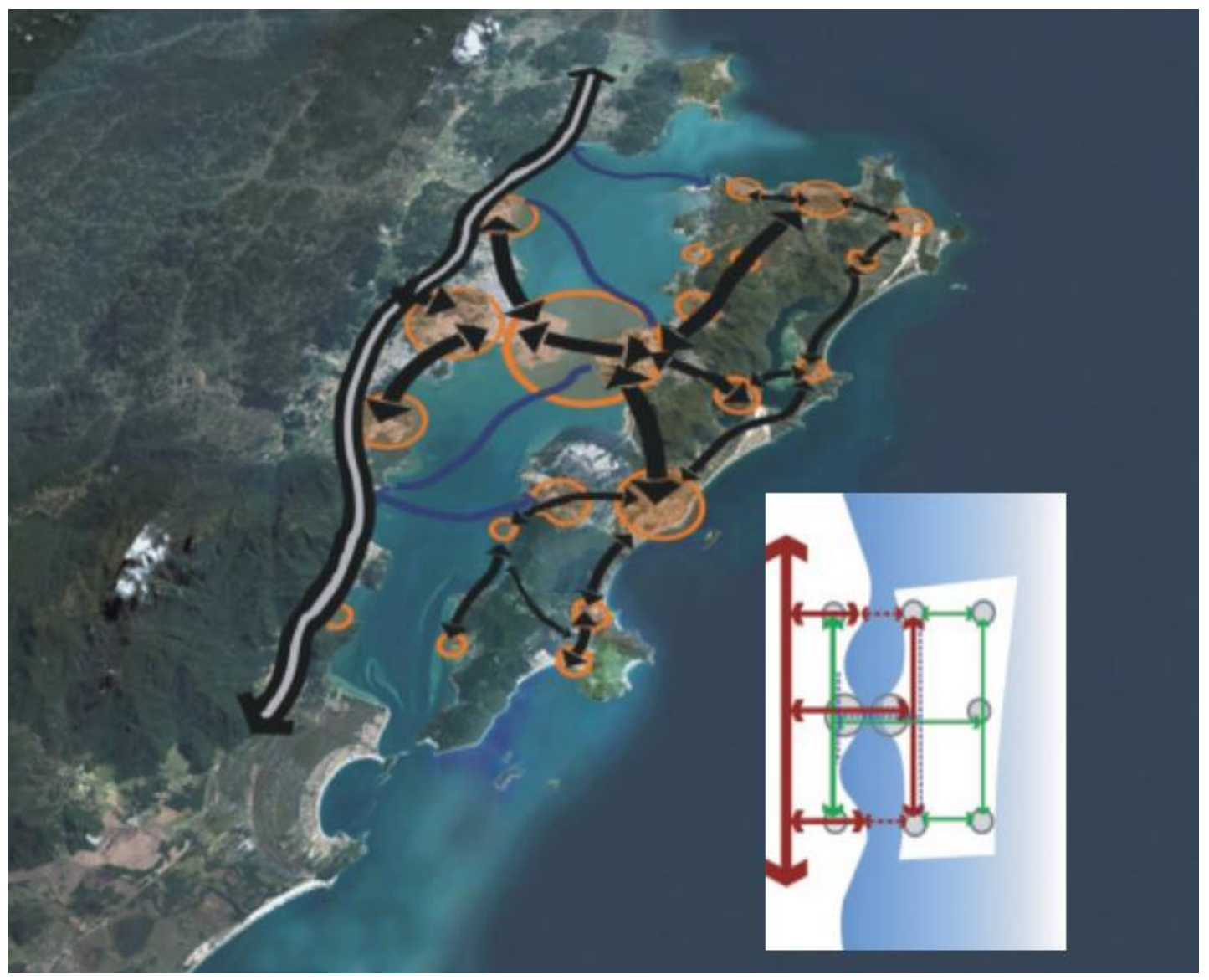

Por outro lado, em relação à mobilidade, contraditoriamente o Floripa 2030 defendeu a manutenção e modernização dos eixos lineares estruturantes da malha viária (figura 6), de maneira a sugerir "um modelo de duplo “H”"” (FLORIPAMANHÃ, 2008, p. 52) sobre o qual propõe um programa de adensamento junto à criação de corredores de transporte coletivo, apresentando pela primeira vez - embora sem nomear explicitamente - o conceito do Bus Rapid Transit (BRT). As sobreposições dessas propostas podem ser compreendidas na figura acima.

PLAMUS: criado em 2013, consistiu em uma série de diretrizes e recomendações de escala regional para a mobilidade dos 13 municípios que compõem oficialmente a Grande Florianópolis, resultantes de diversos estudos financiados pelo Banco Nacional do Desenvolvimento Econômico e Social (BNDES) com acompanhamento do governo do estado de Santa Catarina. Contudo, seu diagnóstico técnico foi ao encontro 
do apresentado pelo Floripa 2030: assume-se que a região cresceu de maneira linear e concentrando fluxos no centro de Florianópolis. Neste sentido, o PLAMUS igualmente propôs a criação de novas centralidades dotadas de infraestrutura e serviços com vistas a reduzir deslocamentos e, ao mesmo tempo, previu uma atualização da conexão entre as centralidades através dos eixos já estabelecidos, propondo também o desenvolvimento através do modelo "duplo H".

No entanto, há duas diferenças objetivas quanto às propostas. Primeiro sobre o Duplo H: enquanto o Floripa 2030 o propôs como solução municipal, o PLAMUS o localizou na região metropolitana, em área correspondente ao contorno viário da Grande Florianópolis, atualmente em fase final de construção (figura 7 - destaque do contorno viário em roxo). A segunda distinção aparece quando o PLAMUS assume o BRT como proposta viável para estruturar o transporte de massa na região, conforme detalhado:

Figura 7. proposta rodoviarista de transporte do PLAMUS. Fonte: extraído de PLAMUS (2015, p. 33).

\section{O desenvolvimento orientado balanceia os fluxos de origem e destino da RMF, reduzindo a migração pendular, são necessários $\mathrm{R}$ \$ 2,0 Bi em investimentos}

Desenvolvimento Orientado

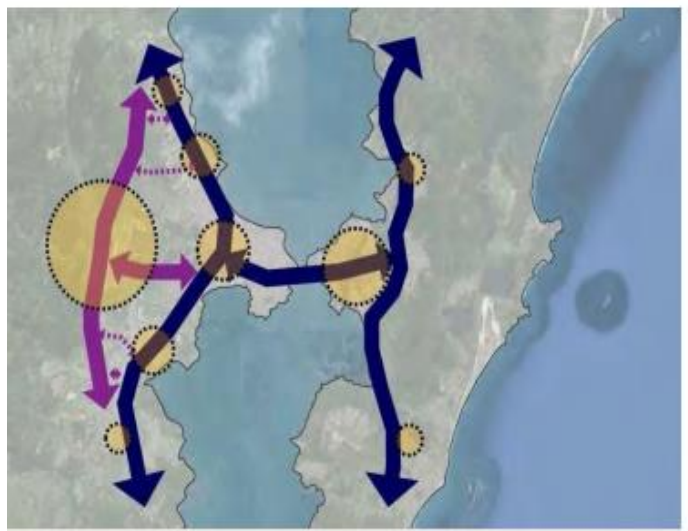

Estruturação da porção oeste do continente, criando centralidades fora da ilha, aplicando conceitos de Desenvolvimento Orientado pelo Transporte

Exige a construção de $73 \mathrm{~km}$ de infraestrutura viária Considera premissas semelhantes ao cenário BRT Revisão das rotas de ônibus e integração tarifária ( $R \$ 2,65$ por viagem)

Fonte: Equipe Plamus
Ano: 2020
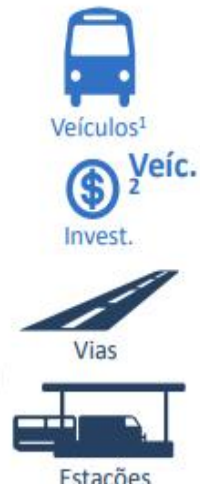

Estações

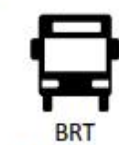

678 comuns

396

articulados

$\mathrm{R} \$ 490 \mathrm{M}$

$122 \mathrm{~km}$

133 simples

9 duplas

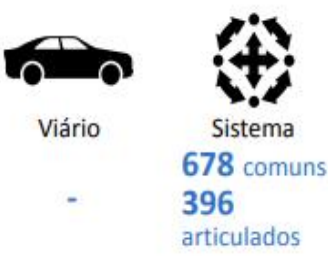

$\mathrm{R} \$ 490 \mathrm{M}$

$73 \mathrm{~km}$

142 estações

R\$ 1.705

$\mathrm{M}$

R\$ 2.195

$\mathrm{M}$

Em síntese, ambas propuseram solucionar a mobilidade adaptando os eixos $\mathrm{H}$ estruturantes de alta densidade e descentralizando os serviços. Estas são exatamente as diretrizes mais facilmente enxergadas na promulgação do PDP (FLORIANÓPOLIS, 2014). Apesar do BRT ser proposta para organizar e agilizar o transporte de massa frente ao comprovado colapso da mobilidade cotidiana de Florianópolis, sua estruturação através do - assim chamado - "eixo duplo H" não parece ser capaz de romper com as descontinuidades 
territoriais colocadas historicamente pelo paradigma rodoviarista-modernista. Além disso, questiona-se em que medida é possível, na escala urbana, empreender planejamento combinando linearidade e multicentralidade - padrões conceitualmente antagônicos. Por último, lembra-se ainda que o BRT, apesar do seu potencial de deslocamento, ainda é um transporte de matriz rodoviarista, e por isto não convalida o modelo de eixos estruturantes sobre as multicentralidades, nem oferece, a longo prazo, respostas sociais e ambientais satisfatórias às problemáticas contemporâneas, entre elas as de poluição e renovação da matriz energética.

\section{CONSIDERAÇÕES FINAIS}

Este artigo analisou a mobilidade urbana em Florianópolis tendo como fio condutor o entendimento de que os processos urbanos desenvolvidos no modo de produção capitalista podem ser compreendidos a partir das complexidades intrínsecas à sua própria essência espacial, isto é, como o resultado das ações engendradas por seus agentes produtores ao longo do tempo. Desta forma, inferiu-se sobre como os planos de desenvolvimento da cidade, concebidos ao longo do Século XX na esteira do modelo urbano rodoviaristamodernista - por sua vez, impregnado na crença hegemônica da tecnocracia - sucederam na constituição de uma mobilidade cotidiana, menos análoga àquela imaginada inicialmente do que íntima a uma cidade cuja área central concentra a maioria da oferta de serviços de toda região metropolitana. Consequentemente, orientando os deslocamentos de maneira linear e garantindo prioridade ao transporte motorizado individual sobre o coletivo e sobre os modos não motorizados, bem como conferindo vantagem a quem pode acessá-lo.

A superação deste desarmonioso processo de deslocamento no espaço urbano tornou-se possível, no Brasil, com a ascensão, sobretudo na década de 2000, de um paradigma de mobilidade respaldado nos recentes preceitos jurídicos garantidores do direito à cidade ${ }^{14}$ e sustentabilidade, levando as cidades, forçosamente, a elaborarem novas estratégias de ordenamento territorial alinhadas a esta perspectiva. Assim, o atual Plano Diretor de Florianópolis é resultado de uma série de diagnósticos cujas interpretações mais significativas para a mobilidade apropriadamente identificaram a necessidade de dotar a cidade de novas centralidades como medida de superação da condição funcionalista, vigente até então.

Contudo, as respectivas propostas para gerar tais multicentralidades (ou polinuclearidades) encampadas pelo Plano Diretor não aspiraram superar o desenvolvimento linear, que é o próprio reflexo da estruturação territorial a ser sobrepujado pelo novo paradigma. Ao contrário, verificou-se que os "eixos H", através de suas adaptações à priorização para implantação do sistema BRT, foram eminentemente adotados como solução para conectar as novas centralidades umas às outras, bem como ao ainda imperante centro

14 Não necessariamente na conceituação lefebvriana, mas em relação ao acesso aos meios de transporte coletivos, motorizados ou não. 
metropolitano. Embora atenda parcialmente ao pleito de suprimir gradativamente a hegemonia do automóvel individual sobre o espaço urbano, não é possível depreender tal solução na esteira da mobilidade cotidiana desejável. Isto é, voltada a atender as distintas demandas de deslocamento das pessoas pelo espaço, por duas razões autônomas entre si, porém indissociáveis e subsequentes: i) esse expediente ainda se circunscreve em um transporte de matriz rodoviarista que utiliza pneus, desgasta estradas, engrenagens e consome combustíveis não-renováveis ao melhor estilo lecorbusiano, não rompendo, portanto com o próprio habitus modernista de pensar a cidade; e ii) a reprodução desse habitus igualmente não rompe sequer com a primazia burguesa de constituição das cidades, revelando, em última análise, uma condição socioespacialmente segregadora que lhe é inerente e imutável.

Portanto, o estado da arte da política de mobilidade de Florianópolis não coaduna com o estado da arte da mobilidade, em âmbito teórico e legal, estabelecido nacionalmente. Ao mesmo tempo, o processo histórico mostra que da constituição de uma nova agenda para o desenvolvimento urbano e/ou regional à promulgação de um novo Plano Diretor há uma janela temporal na qual quaisquer sugerências de longo prazo direcionadas a uma pauta integralmente favorável à mobilidade cotidiana e sustentável (pautadas no estímulo da organização espacial de multicentralidades/polinuclearidades) seriam incipientes para estas breves considerações finais, constituindo tarefa de fôlego para trabalhos futuros. Ainda assim, é possível apontar, à guisa de conclusão, caminhos igualmente progressistas cujos desdobramentos podem levar a propostas de mitigação do paradigma estabelecido localmente em curto e médio prazo, tais como: gratuidade da tarifa do transporte coletivo, conexão intermodal eficiente e acessível entre o transporte de massa e modos não motorizados de deslocamento, políticas perenes visando desincentivar o uso do automóvel individual, dentre outras.

\section{REFERÊNCIAS}

ABRAMO, Pedro. A Cidade COM-FUSA: A mão inoxidável do mercado e a produção da estrutura urbana nas grandes metrópoles latino-americanas. Revista Brasileira de Estudos Urbanos e Regionais. v.9, n.2, p. 25-55, nov. 2007. Disponível em: https://doi.org/10.22296/2317-1529.2007v9n2. Acesso em 03 Maio 2018.

AFFONSO, Nazareno Stanislau. Mobilidade sustentável no Brasil: é possível? In: ALMEIDA, Evaristo. (Org.). Mobilidade urbana no Brasil. São Paulo: Editora Fundação Perseu Abramo, 2016. p. 83-96.

AGUIAR, André Ruas. Analisando o Floripa 2030: um modelo hegemônico de cidade. Dissertação (mestrado) - Curso de Urbanismo, História e Arquitetura da Cidade, Centro de Ciências Tecnológicas, Universidade Federal de Santa Catarina, Florianópolis, 2015. Disponível em: https://repositorio.ufsc.br/handle/123456789/160655. Acesso em: 12 Julho 2018.

BALBIM, Renato. Mobilidade urbana: uma abordagem sistêmica. 2 ed. São Paulo: IPEA, 2016.

BALDRAIA, André. Notas sobre mobilidade cotidiana cinco anos após a política nacional de mobilidade urbana. Geofronter, Campo Grande, n.3, v.2, Volume Especial, p. 30-4. 2017.

BARAT, Josef. A Evolução dos Transportes no Brasil. Rio de Janeiro: IBGE/IPEA, 1978. 
BASTOS, José Messias. Urbanização, comércio e pequena produção mercantil pesqueira na llha de Santa Catarina. In: SANTOS, Mauricio Aurélio dos. Ensaios sobre Santa Catarina. Florianópolis: Ed Letras Contemporâneas, 2000.

BRASIL, 2012. Lei Federal no 12.587 de 03 de janeiro de 2012 (Política Nacional de Mobilidade Urbana) [online]. Disponível em: https://www.planalto.gov.br/ccivil_03/_ato2011-2014/2012/lei112587.htm. Acesso em: 05 Maio 2018.

CORRÊA, Roberto Lobato. O Espaço Urbano. São Paulo: Ática, 1989.

COSTA, Emannuel dos Santos. A Cidade do Automóvel: relações de influência entre o carro e o planejamento urbano modernista em Florianópolis. Dissertação (mestrado) - Curso de Urbanismo, História e Arquitetura da Cidade, Centro de Ciências Tecnológicas, Universidade Federal de Santa Catarina, Florianópolis, 2014. Disponível em: https://core.ac.uk/download/pdf/30405286.pdf. Acesso em 09 Setembro 2018.

CRAVO, Leandro José de Almeida. ROSSETO, Adriana Marques. STORCH, Adriana Carvalho da Silva. Florianópolis: Os Planos diretores aprovados entre 1955 e 2014. In: 12 Congresso de Cadastro Técnico Multifinalitário e Gestão Territorial. Florianópolis, 2016. Disponível em: http://www.ocs.cobrac.ufsc.br/index.php/cobrac/cobrac2016/paper/viewFile/312/43.Acesso em: 09 Maio 2018.

DIÁRIO CATARINENSE. Florianópolis é pior cidade do país para dirigir, segundo índice do Waze. 03/11/2017 Disponível em: http://dc.clicrbs.com.br/sc/noticias/noticia/2017/11/florianopolis-e-pior-cidade-do-pais-para-dirigir-segundo-indice-do-waze9980930.html. Acesso em: 10 Julho 2018.

DIÁRIO CATARINENSE. Florianópolis tem pior mobilidade urbana do Brasil. 26/05/2000 Disponível em:

http://dc.clicrbs.com.br/sc/noticias/noticia/2009/05/florianopolis-tem-pior-mobilidade-urbana-do-brasil-2523317.html. Acesso em: 10 Julho 2018.

DUANE, Andres. PLATER-ZYBERK, Elisabeth. SPECK, Jeff. Suburban Nation: The Rise of Sprawl and the Decline of the American Dream. New York: North Point Press, 2010. 320 p.

FLORIANÓPOLIS, 1976. Sub-emenda Substitutiva Ao Projeto de Lei № 1.142: Altera o Plano Urbano da cidade e dá outra providências. Florianópolis: Câmara Municipal de Vereadores.

FLORIANÓPOLIS, 1985. Lei $\mathbf{n}$ o 2193-85: dispõe sobre o zoneamento do uso e a ocupação do solo nos balneários da Ilha de Santa Catarina. Florianópolis: Câmara Municipal de Vereadores.

FLORIANÓPOLIS, 1997. Lei Compelmentar no 001/97. Florianópolis: Câmara Municipal de Vereadores.

FLORIANÓPOLIS, 2014. Lei Complementar no482/2014: institui o Plano Diretor de Urbanismo do Município de Florianópolis que dispõe sobre a Política de Desenvolvimento Urbano, o Plano de Uso e Ocupação, os Instrumentos Urbanísticos e o Sistema de Gestão. Florianópolis: Prefeitura Municipal. Disponível em: http://planodiretorflorianopolis.webflow.io/. Acesso em: 10 Julho 2018.

FLORIPAMANHÃ. Floripa 2030: agenda estratégica de desenvolvimento sustentável de Florianópolis na região. Florianópolis, 2018. Disponível em: http://floripamanha1.hospedagemdesites.ws/wp-content/uploads/2012/05/floripa2030-livro-2edicao.pdf. Acesso em: 10 Julho 2018.

GOMIDE, Alexandre de Ávila. Mobilidade Urbana, Iniquidade e Políticas Sociais. In: Diretoria de Estudos Sociais (Org.). Políticas Sociais, Acompanhamento e Análises. Brasília: Ipea, 2006. p. 242-250. Disponível em:

http://repositorio.ipea.gov.br/handle/11058/4511. Acesso em 06 Maio 2018.

GORZ, André. A Ideologia Social do Automóvel in: LUDD, Ned. Apocalipse Motorizado: A Tirania do Automóvel em um Planeta Poluído. São Paulo: Conrad Editora do Brasil, 2004.

LENZI, Maria Helena.; GONÇALVES, Tiago Cargnin. Florianópolis: as imagens da cidade e a urbanização turística do "paraíso". Revista Geográfica de América Central Número Especial EGAL, 2011- Costa Rica II Semestre 2011 pp. 1-18.

LÖWY, Michael. A Jaula de Aço: Max Weber e o marxismo weberiano. 1 ed. São Paulo: Boitempo, 2014.

MAMIGONIAN, Armen. As conquistas marítimas portuguesas e a incorporação do litoral de Santa Catarina. In: ANDRADE, Manuel Correa et al (org). 0 mundo que o português criou: Brasil. século XVI. Recife: CNPQ/Fjn, 1998.

MAMIGONIAN, Armen. Habitat rural açoriano. In: SANTA CATARINA. Departamento Estadual de Geografia e Cartografia. Atlas geográfico de Santa Catarina. Florianópolis: DEGC/SC, 1958.

MUNFORD, Lewis. A cidade na História: suas origens, desenvolvimento e perspectivas. 2 ed. São Paulo: Martins Fontes, 1982.

NEWSWEEK. The Ten Most Dynamic Cities. 07/02/2006. Disponível em: https://www.newsweek.com/ten-most-dynamic-cities112629. Acesso em: 10 Julho 2018. 
PEREIRA, Elson Manoel. Qual planejamento urbano no contexto da sociedade da incerteza? Florianópolis e seus planos diretores. Geosul, Florianópolis, v. 25, n. 49, p 103-121, jan./jun. 2010. Disponível em: http://labcs.ufsc.br/files/2011/12/09.-PEREIRA-E.M.Qual-planejamento-urbano-no-contexto-da-sociedade-da-incerteza.pdf. Acesso em 27 Maio 2018.

PLAMUS, Plano de Mobilidade Urbana Sustentável da Grande Florianópolis. Apresentação Frente Parlamentar da Assembleia Legislativa do Estado de Santa Catarina. Florianópolis, 2015. Disponível em:

http://www.plamus.com.br/arquivos/plamus apresentacao frente parlamentar alesc.pdf. Acesso em: 10 Julho 2018.

PNUD; IPEA; FJP. O Índice de Desenvolvimento Humano Municipal Brasileiro. Brasília: Pnud Brasil, 2013. Disponível em: http://www.atlasbrasil.org.br/2013/data/rawData/publicacao atlas municipal pt.pdf. Acesso em: 08 Julho 2018.

RANGEL, Ignácio. Obras Reunidas (dois volumes) Benjamin, Cesar (org). Rio de Janeiro: Contraponto, 2005.

RIBEIRO, Darcy. $O$ processo civilizatório. São Paulo: Editora Folha de São Paulo, 2000.

ROCHA, Geisa Silveira da. Florianópolis e seus dois primeiros planos diretores: entre discurso e realizações. In: 2o Seminário Nacional de Planejamento e Desenvolvimento. Florianópolis, 2014. Disponível em: http://200.19.73.116/anais2/wpcontent/uploads/2015/08/643.pdf. Acesso em 09/07/2018

RODRIGUES DA SILVA, Antônio Nelson. COSTA, Marcela da Silva. MACEDO, Márcia Helena. Planejamento integrado, organização espacial e mobilidade sustentável no contexto de cidades brasileiras. In: BALBIM, Renato. KRAUSE, Cleandro. LINKE, Clarisse Cunha. (Orgs.). Cidade e movimento: mobilidades e interações no desenvolvimento urbano. Brasília: Ipea: ITDP, 2016. p. 81-100.

SANTOS, Milton. Sociedade e espaço: a formação social como teoria e como método. Boletim Paulista de Geografia, n. 54. Pp. 8197. Jun. 1977.

SILVA, Celia. Maria. Ganchos SC: Ascensão e decadência da pequena produção mercantil pesqueira. Florianópolis: Editora da UFSC, 1992.

SIMÕES JR, José Geraldo. Cenários de Modernidade: os projetos urbanos das capitais brasileiras no início da república. In: III Fórum de Pesquisa FAU-Mackenzie, 2007. p. 1-16. Disponível em:

http://www.mackenzie.br/fileadmin/Graduacao/FAU/Publicacoes/PDF IIIForum a/MACK III FORUM JOSE GERALDO.pdf. Acesso em: 20 Junho 2018.

SOUZA, Juliana Pinto. O plano diretor de 1952-1955 e as repercussões na estrutura urbana de Florianópolis. Dissertação (mestrado) - Curso de Urbanismo, História e Arquitetura da Cidade, Centro de Ciências Tecnológicas, Universidade Federal de Santa Catarina, Florianópolis, 2014. Disponível em https://repositorio.ufsc.br/handle/123456789/94156. Acesso em 20 Maio 2018.

SPOSITO, Maria Encarncação Beltrão. A Produção do Espaço Urbano: escalas, diferenças e desiguladades socioespaciais. in: CARLOS, Ana Fani Alessandri. SOUZA, Marcelo Lopes. SPOSITO, Maria Encarncação Beltrão. (org.) A Produção do Espaço Urbano. São Paulo: Contexto, 2011.

SUGAI, Maria Inês. As intervenções-viárias e as transformações do espaço urbano: a via de contorno Norte Ilha. Dissertação (Mestrado) - Curso de Arquitetura e Urbanismo, Faculdade de Arquitetura e Urbanismo, Universidade de São Paulo, São Paulo, 1994.

THE NEW YORK TIMES. The Place to Be: Florianópolis, Brazil. 08/01/2009. Disponível em: https://www.nytimes.com/2009/01/11/travel/11party.html? r=0. Acesso em: 10 Julho 2018.

VASCONCELLOS, Eduardo Alcântara. Mobilidade cotidiana, segregação e exclusão. In: BALBIM, Renato. KRAUSE, Cleandro. LINKE, Clarisse Cunha. (Orgs.). Cidade e movimento: mobilidades e interações no desenvolvimento urbano. Brasília: Ipea: ITDP, 2016. p. 57-80.

WHITACKER, Arthur. Uma discussão sobre morfologia urbana e a articulaçaõ de níveis diferentes de urbanização. in. Cidades Médias: Espaço em transição. São Paulo: Expressão Popular, 2007. 